\title{
Biomineralization and detoxification of toxic compounds, otavite production by Cupriavidus campinensis S14E4C
}

\author{
GORKHMAZ ABBASZADE ${ }^{1}$, KAROLY BOKA ${ }^{2}$, LASZLO \\ ARADI $^{3}$, CSABA SZABÓ $^{4}$ AND ERIKA TOTH ${ }^{5}$ \\ ${ }^{1}$ Eötvös Lorand University \\ ${ }^{2}$ Eötvös Loránd University \\ ${ }^{3}$ Lithosphere Fluid Research Lab, Eötvös University \\ ${ }^{4}$ Eötvös University \\ ${ }^{5}$ Institute of Biology, Eötvös Loránd University \\ Presenting Author: gorkhmaz@caesar.elte.hu
}

Heavy metal(loid) contamination is major environmental concern, caused by widespread anthropogenic activities. Most of the heavy metal(loid)s are toxic even in minor amounts and can accumulate in organisms damaging cell structure and deteriorating metabolic processes. The persistence and nondegradable nature of the heavy metal(loid)s makes them difficult to remove from the environment. Current physicochemical remediation technologies contain various disadvantages, besides being extremely expensive. However, usage of microorganisms in bioremediation is one of the cost-effective and environmentally friendly method where soil microorganisms can detoxify contaminants by adsorption, precipitation, or transformation processes.

In this study, bacterial heavy metal(loid)-bearing precipitation produced by the strain Cupriavidus campinensis S14E4C was examined and proved as promising for removal of environmental contaminants.

Exposure to various concentrations of lead, cadmium, mercury and arsenic salts in nutrient media revealed the minimum inhibitory concentration for the strain as $3000 \mathrm{mg} / \mathrm{L} \mathrm{Pb}, 1000$ $\mathrm{mg} / \mathrm{L} \mathrm{Hg}, 600 \mathrm{mg} / \mathrm{L}$ As and $15000 \mathrm{mg} / \mathrm{L} \mathrm{Cd}$. The two weeks old bacterium strains were studied by transmission electron microscopy (TEM). Comprehensive imaging analysis indicated that exposure to $\mathrm{Pb}, \mathrm{As}, \mathrm{Hg}$ and $\mathrm{Cd}$ formed intra and extracellular granules and induced morphological changes. Besides this, in more than $2000 \mathrm{mg} / \mathrm{L} \mathrm{Cd}$ environment the strain precipitated non-soluble $\mathrm{CdSO}_{4} * 8 / 3 \mathrm{H}_{2} \mathrm{O}$ to scarce Cd-mineral, $\mathrm{CdCO}_{3}$ (otavite), detected by Raman spectroscopy. Genomic analysis of the strain indicated number of plasmid mediated metal resistance genes, play role in the resistance against cadmium species. In this regard, the biomineralization product, non-toxic otavite mineral is a resistance mechanism of $\mathrm{C}$. campinensis S14E4C to overcome environmental stress conditions, which can be used as strategy for bioremediation of toxic compounds. 